\author{
Arto Mutanen \\ Finnish Naval Academy, PO-Box 5 (Suomenlinna), FI-00191 Helsinki \\ arto.mutanen@gmail.com
}

\title{
Science and Communication
}

\begin{abstract}
Communication in science is basically established as communication between colloquies within a field of science. Scientific journals, scientific conferences etc. are based on this principle. For example, the notion of peer reviewer supposes such a collegial, monodisciplinary framework. However, multidisciplinary research and engagement with practical problems enforce us to look at the situation in a new way. What can a multidisciplinary discussion mean? How to build up such a multidisciplinary discussion? Is such a discussion merely a struggle between incompatible opinions - science war? In a proper dialogue the final referee should be the practice, not a scientific theory.
\end{abstract}

\section{Key words}

philosophy of science, interrogative model, monodisciplinary research, multidisciplinary research, science war, dialogue

\section{Introduction}

If we would like to know about, for example, global warming, we would like to ask specialists, i.e. scientists, about it. Why would we think of scientists as the most reliable sources of information about global warming? Are they really such a source? Even if the answer were affirmative, it would not help us very much. If one wants to know about global warming, it is not good enough to ask a scientist about it - one ought to ask a scientist who is a specialist in the field. But how can a layman recognize such a specialist? Global warming is a problem related to nature but also a societal problem: is the intended source of relevant information a natural scientist or a social scientist?

The problem of recognizing the relevant specialist is a real problem. Global warming is an example of a practical problem in which there are several different aspects that could be understood as relevant, but no single specialist can master all of them. If one does not master some of the aspects of the problem, how can he or she evaluate the whole problem? This problem we meet not only in such global problems as global warming, but in all practical problems. ${ }^{1}$

This opens several different but related problems. In the following, we will consider some of these. Our consideration in this paper is a philosophical analysis of the problematics. In philosophy of science, the characterization is 
conceptual and intentionally idealized. However, if the phrasing of a question in philosophy of science is not known, the whole discussion can be misunderstood. This misunderstanding is called mystification of science. However, the mystification of science is not merely misunderstanding philosophy of science; the language used in philosophy of science can be read in such a way that the mystification is a natural interpretation of the texts.

A reaction to the mystification of science is demystification of science. This means that a more realistic or more naturalistic attitude to the scientific approach will be taken. This means that science will be seen as a human enterprise in which all human reality is present. Not all scientists are looking for truth, not all scientists are trustworthy people and so on. However, this does not imply that a science as a collective enterprise would collapse.

A radical interpretation of demystification is called remystification. In such remystification, mystification takes place but in the opposite direction. Science is seen as an enterprise of power. However, the result is not as intended. The result is a kind of science war in which proper scientific dialogue is not possible.

In science, communication is both written and oral. In communication, understanding and misunderstanding are always present. Scientific communication should be rational. Rational communication is not easily achieved. There are several different kinds of obstacles making open, critical communication impossible.

\section{Mystification of science}

Science is taken seriously: scientific research is something that serious men are doing; the result of scientific research is called scientific knowledge, which is the best kind of knowledge a human being can achieve. All this is quite true. This is a kind of standard philosophy of science. ${ }^{2}$ The idea of characterizations like these is that scientific reasoning is in principle of such and such kind. There is nothing wrong in our everyday reasoning even if it does not follow such principles. But if science does not follow such and such principles, we should say that it is bad scientific reasoning or that it is not scientific reasoning at all. That is, these principles give certain kinds of methodological constraints to scientific reasoning. ${ }^{3}$

However, the formulations that can be found in the literature can be interpreted in a different way. To get a sense of this, let us consider the following quote.

"If we endeavour to form our conceptions upon history and life, we remark three classes of men. The first consist of those for whom the chief thing is the qualities of feelings. These men create art. The second consists of the practical men, who carry on the business of the world. They respect nothing but power, and respect power only so far as it [is] exercised. The third class consists of men to whom nothing seems great but reason. If force interests them, it is not its exertion, but in that it has a reason and a law. For the men of the first class, nature is a picture; for men of the second class, it is an opportunity; for the men of the third class, it is a cosmos, so admirable, that to penetrate to its ways seems to them the only thing that makes life worth living."

In the quotation, Peirce formulated three kinds of humans. It is obvious that scientists are of the best kind. Nowadays, this looks like a joke rather than a characterization of an idealized scientific attitude. Science is these days a vocation among the vocations. ${ }^{5}$ So the quotation looks like the talk of a trade union of scientists which is trying to improve the position of science from what it otherwise should be. 
However, such demands impose some more specific characters for scientists. The idea of scientist as a truth seeker imposes some specific characters for scientists. To find out the truth one should be honest. Already Plato formulated such a constraint for truth seekers. Peirce made the following formulation:

"A scientific man must be single-minded and sincere with himself. Otherwise, his love of truth will melt away, at once. He can, therefore, hardly be otherwise than an honest, fair-minded man. True, a few naturalists have been accused of purloining specimens; and some men have been far from judicial in advocating their theories. Both of these faults must be exceedingly deleterious to their scientific ability. But on the whole, scientific men have been the best of the men. It is quite natural, therefore, that a young man who might develop into a scientific man should be a well-conducted person."

The idea is that a scientific man should be of such and such a kind. If such a characterization is interpreted as a factual characterization, the mystification of science takes one step further. However, we should ask why it is so important for a scientist to be honest. The answer will be obvious: if one is looking for truth, honesty is a methodological constraint for such an enterprise. ${ }^{7}$

The value of scientific research is obvious: science has a special place in society. However, nowadays respect is connected to (practical) utility. This can be seen from the role of technology in present day societies. The roots of science are not in such practical utility but in the search for truth. This emphasis imposes that, in a sense, science is not useful but truthful.

"True science is distinctively the study of useless things. For the useful things will get studied without the aid of scientific men. To employ these rare minds on such work is like running a steam engine by burning diamonds."

So, science is looking for truth, not something practically useful. However, why should we, ordinary people, respect such an estranged approach? The only approaches that deserve our respect are of some practical value: science should also earn its place in society by showing the utility it provides. Thus, the quotation takes one more step in the mystification of science.

\section{Demystification of science}

We have seen a mystification process of science. The mystification of science imposes some ideal properties to science and to scientists. The mystification becomes complete because of the change in the values of societies. Free civilization is no longer good enough. The time of Enlightenment is gone. Practical utility has taken the place of free civilization. Science is not developed for such an approach. So, the role of science should be re-evaluated. That is, there is a need for demystification of science.

See for example: Ilkka Niiniluoto, Critical Scientific Realism, Oxford University Press, Oxford 1999.

3

Vincent Fella Hendricks, The Convergence of Scientific Knowledge-A View from the Limit, Kluwer Academic Publishers, Dordrecht 2001.

Charles S. Peirce, Philosophical Writings, Dover Publications, New York 1955, p. 42.
Juha Siltala, Työelämän huonontumisen lyhyt historia (A Short History of the Deterioration of Working Life), Otava, Helsinki 2004.

6

C. S. Peirce, Philosophical Writings, p. 44. 7

Jaakko Hintikka, "Omitting Data: Ethical or Strategic Problem?”, Synthese 145 (2/2005).

8 C. S. Peirce, Philosophical Writings, p. 48. 
The demystifier par excellence is Paul Feyerabend. He says that

"I want to defend society and its inhabitants from all ideologies, science included. All ideologies must be seen in perspective. One must not take them too seriously." 9

Feyerabend says that he is intentionally provocative. ${ }^{10}$ This intention was realized. However, there is a real need for demystification of science. The need is not dependent on the present day decrease in the value of truth seeking, but on the real need for re-evaluation of scientific research. The demystification should be done in an analytical mood. That is, we should analyze actual scientific research work and conceptualizations of scientific research.

The demystification supposes that we will consider more precisely the idealized, methodological and philosophical constraints of science. How are they intended to orient actual scientific research? How should actual scientific research be evaluated? How does actual scientific research work change the methodological and conceptual constraints of research? How can one characterize the scopes of different scientific approaches? To do this, one actually enlarges our knowledge and understanding about science and scientific research work. Such work demystifies science.

To have a better picture, we should take a look at concrete examples. Engineering science is an extremely good example. The history of engineering science is very practical - constructing engines. In engineering science, theoretical knowledge and practical knowledge (skills) are systematically interconnected. Practical knowledge functions basically at the level of everyday experience. The first step in the theorization of practical knowledge is to formulate "rules of thumb" of the practical skills. This explicates the skills and makes them more effective. Moreover, systematization makes the rules more effective. Systematized rules make systematic discussion (research) and teaching possible. Following von Wright, ${ }^{11}$ these rules are called 'technical norms'. It is possible to collect technical norms in a systematic way; and this collection may take the form of a scientific theory. ${ }^{12}$ It is interesting to note that engineering science cannot be located into our classification of research work above.

In a sense, engineering science is a science of practical value. However, in present day discussion engineering science, too, is demanded to take a step towards practicality. ${ }^{13}$ The step toward practicality is not easy to take. The engineering scientist is trying to create working engines of practical use. This supposes that there is proper scientific research and testing. ${ }^{14}$ Sometimes the step towards practicality is intended to mean something connected to practical innovation. ${ }^{15}$ However, according to engineering science, this seems to be a misinterpretation of research in engineering science. ${ }^{16}$

There is a proper need for demystification of science. Feyerabend has done a lot of work in this direction. However, the present day discussion seems to be directed at some other kinds of problems instead of general philosophy of science, which includes both Peirce and Feyerabend. Let us take a look at the philosophy of science.

\section{Philosophy of science}

In philosophy of science, one central problem is to characterize the very nature of scientific research work. For example, the title of Chalmers' book What is this thing called science? ${ }^{17}$ is in this sense illuminating. However, to answer questions like the one in the title is not an easy task to do. The answer looked at is not a mere description of actual research work, but at the same 
time it should give some normative (prescriptive) characterizations of what scientific research work should be. The interconnection of the factual and the conceptual (normative) is a characteristic property of philosophical work. ${ }^{18}$

"Working scientists often remain content with an institutional characterization of science - science is simply what they have learned to do through their scientific education - philosophers try to formulate and bring forward alternative views about the nature of science and submit them to open and to critical discussion." 19

In actual scientific work, the normative aspect is only implicitly present. The research work is carried out within a tradition and reflection on the tradition cannot be done at the same time. This implies that the (empirical) scientist cannot reflect on the fundamentals of his or her research work during his or her actual research work. The research work is so demanding that there is no time to do such systematic reflection. ${ }^{20}$ So, the normative part of the characterization is thin - even if it on occasion is disguised with philosophical notions. On the other hand, philosophers of science do not have close connections to actual research groups. So, the descriptive part of the philosophy is not updated, even if sometimes it is disguised with several empirical details. ${ }^{21}$

Popper characterized that the most fundamental question in philosophy of science is the demarcation problem. He characterizes the problem as follows:

"The problem of finding a criterion which would enable us to distinguish between the empirical sciences on the one hand, and mathematics and logic as well as 'metaphysical' systems on the other, I call the problem of demarcation." 22

Paul Feyerabend, "How to Defend Society against Science", in: Evan Selinger \& Robert P. Crease (eds.), The Philosophy of Expertise, Columbia University Press, New York 2006, pp. 358-369, here p. 359.

10

Ibid., p. 358

11

Georg Henrik von Wright, Norm and Action, Routledge \& Kegan Paul, London 1963.

12

Ilkka Niiniluoto, "The Aim and Structure of Applied Research", Erkenntnis 38 (1993), pp. $1-21$.

13

See: P. Reason \& H. Bradbury, Handbook of Action Research.

14

I. Niiniluoto, "The Aim and Structure of Applied Research".

15

See: Henry Chesbrough, Open Innovation: The New Imperative for Creating and Profiting from Technology, Harvard Business School Press, Boston 2003; and Erich von Hippel, Democratizing Innovation, MIT Press, Cambridge (MA) 2005.
Vincent Fella Hendricks, Arne Jakobsen \& Stig Andur Pedersen, "Identification of Matrices in Science and Engineering", Journal for General Philosophy of Science 31 (2/2000), pp. 277-305.

17

Alan Chalmers, What is this thing called science?, Queensland University Press \& Open University Press, Brisbane 1976 ( $1^{\text {st }}$ edition).

18

See: Jaakko Hintikka, Socratic Epistemology, Cambridge University Press, New York 2007. 19

Ilkka Niiniluoto, Is Science Progressive?, Reidel, Dordrecht 2001, p. 1.

20

Cf. Arto Mutanen (ed.), The Many Faces of Military Studies: A Search for Fundamental Questions, Publications of the Finish Naval Academy, Helsinki 2008, in which philosophers and researchers together are looking for the fundamental questions of military studies. 21

See: Ilkka Niiniluoto, Critical Scientific Realism, Oxford University Press, Oxford 1999; and I. Niiniluoto, Is Science Progressive?.

22

Karl Popper, The Logic of Scientific Discovery, Harper \& Row, New York 1959, p. 34. 
The problem of demarcation searches for the criteria to distinguish empirical science from non-empirical approaches. In the positivistic tradition, the idea was to characterize the demarcation line in a naturalistic way. Positivists emphasized the role of direct observations in scientific research. The observations give a firm basis for the whole (empirical) science. ${ }^{23}$

The idea was that the research procedure runs through observations to a generalization. At the bottom were observations and observation sentences. All the scientific sentences should be traced back to these observation sentences. This implied that the reduction and, especially, climb from observation sentences to generalizations become a major problem. Thus, the problem of induction became the fundamental problem for positivists. ${ }^{24}$ The problem of induction is essentially a problem of justification; verification is just an extreme case of justification. ${ }^{25}$ For positivists, induction became a central problem of characterizing meaningful sentences:

"If there is no possible way to determine whether a statement is true then that statement has no meaning whatsoever. For the meaning of a statement is the method of its verification."26

However, answers to the problem of induction do not provide answers to the problem of demarcation. This is the reason why Popper emphasized, besides the problem of induction, the problem of demarcation. The problem of demarcation is the more fundamental one:

"Of these two problems - the source of nearly all the other problems of the theory of knowledge - the problem of demarcation is, I think, the more fundamental. Indeed, the main reason why epistemologists with empiricist leanings tend to pin their faith to the 'method of induction' seems to be their belief that this method alone can provide a suitable criterion of demarcation. This applies especially to those empiricists who follow the flag of 'positivism'."27

Usually, research work is divided into three different but connected classes. Basic inquiry is characterized as "the systematic pursuit of new scientific knowledge without the aim of specific application". Applied inquiry is characterized as "the pursuit of knowledge with the aim of obtaining a special goal". Development is characterized as the use of the results of scientific inquiry to develop new products, methods, and means of production. ${ }^{28}$ The division is not clear at all. However, for us it is enough to have this conceptual classification. We need not consider more closely how such classification can be empirically implemented.

\section{Interrogative model of inquiry}

A natural way to analyze scientific inquiry is to characterize it as a process of questions and answers - as an interrogation process. The interrogative model of inquiry developed by professor Jaakko Hintikka together with his colleagues gives a systematic characterization of inquiry as an interrogative process. However, the interrogative approach to scientific reasoning is not just one approach to its subject among many.

Historically, the Socratic method of questioning or elenchus was the first systematic approach to interrogative reasoning. Plato systematized it into a practice of questioning games in his dialogues. In the Topica, Aristotle developed a strategic theory of such interrogative reasoning. ${ }^{29}$

Logically, the interrogative approach can be seen as an interesting generalization of usual deductive logic. One's line of reasoning can be expressed in the form of a series of sentences. The relationship between the sentences is of logical and philosophical importance. If the information of a given sentence 
is contained in the information of earlier sentences in the series, the inference step is logical (deductive). If the information is not contained in the information of earlier sentences, the information given by the new sentence is properly new. There must be a source or sources of such information. To be reasonable, the inquirer must know the sources of information: what kind of information can be found out, how reliable is the source, etc. Without such information, we could not speak about reasonable reasoning but mere guesswork.

The information comes into the reasoning process as a response to the inquirer's initiative: The source of the information is known by the inquirer. So the inquirer can make a strategic plan for his or her initiatives. The initiatives can be understood as questions posed by the inquirer, and the responses as answers to the questions. Thus, such a rational line of reasoning can in principle be thought of as a strategic interrogative process. ${ }^{30}$

The interrogative model can be characterized by using logical tools. The basic idea is just the same as in first order deductive logic, except that the reasoning is connected to some particular empirical basis. The inquirer has some background information which is coded as a theory, say T. For simplicity, the empirical basis into which the reasoning is anchored is a model $\mathrm{M}$ of $\mathrm{T}, \mathrm{M}$ = $\mathrm{T}$. The conclusion that the inquirer is trying to infer is $\mathrm{C}$. If the inquirer can infer $\mathrm{C}$ from $\mathrm{T}$ by using some information from the model $\mathrm{M}$, then we say that $\mathrm{C}$ is interrogatively derivable from $\mathrm{T}$ in $\mathrm{M}$ :

$$
\text { (1) M:T F C. }
$$

To see the logical and philosophical importance of the model, let us mention the following facts. The notion of interrogative derivability generalizes in an interesting way both the familiar notion of truth in a model, i.e. $\mathrm{M} \vDash \mathrm{C}$, and the equally familiar notion of logical consequence, $\mathrm{T}-\mathrm{C}$. The former relation is obtained as a special case of (1) when there is no background information at all and all questions are answerable. The latter is obtained when no questions can be asked. ${ }^{31}$

In (1), a scientist is trying to interrogatively derive $\mathrm{C}$ from $\mathrm{T}$ in $\mathrm{M}$. However, to do this the framework formulated by formula (1) has to be known by the inquirer. That is, both the theory $\mathrm{T}$ and the application $\mathrm{M}$ of the theory have to be known by the inquirer. Moreover, to have scientific research there must

23

K. Popper, The Logic of Scientific Discovery; and Jaakko Hintikka, "The Logic of Science as Model-Oriented Logic", in: Peter D. Asquith \& Phillip Kitcher (eds.), PSA 1984 1, Philosophy of Science Association, East Lansing 1984, pp. 177-185.

24

K. Popper, The Logic of Scientific Discovery; and J. Hintikka, Socratic Epistemology.

25

Jaakko Hintikka, Arto Mutanen \& Ilpo Halonen, "Interrogative Logic as a General Theory of Reasoning", in: Ralph H. Johnson \& John Woods (eds.), Handbook of Practical Reasoning, Kluwer Academic, Dordrecht 2002.

26

Waisman, 1930, quote from K. Popper, The Logic of Scientific Discovery, p. 40.
K. Popper, The Logic of Scientific Discovery, p. 34.

28

See: I. Niiniluoto, Is Science Progressive? 29

J. Hintikka, A. Mutanen \& I. Halonen, "Interrogative Logic as a General Theory of Reasoning".

30

Ibid.

31

J. Hintikka, A. Mutanen \& I. Halonen, "Interrogative Logic as a General Theory of Reasoning"; and J. Hintikka, Socratic Epistemology. 
be a scientific research group which shares the interpretation. In Kuhnian language we may say that the research group has a common paradigm which directs the interpretation of the theory and its application, as well as the observations, experiments and results.

\section{Scientific journals}

A present day tradition in publishing is the scientific journal in a specified field of science. There exist a huge number of journals, each of which specializes in a particular field of science. In a mature field of science this tradition is justified. For example, in quantum mechanics there is a long tradition which characterizes the scientific publication practices. This implies that the framework for journals is well defined.

One central factor for scientific journals is internal quality assurance. One main part in this quality assurance is the peer review system. That is, an anonymous colleague works as a referee. The anonymity is, of course, central to this process. However, even more central is the requirement that the colleague is working in the same field of inquiry. In a mature field of science the notion of the same field is quite well defined. The peer reviewer functions as a censor: he or she qualifies the submitted papers. To perform this function as intended, the field of science has to be well characterized: the writer and the reviewer are in a natural sense engaging in a common discussion - this presupposes common understanding about central problems and potential solutions. ${ }^{32}$ According to the characterization above, they share the interpretation of formula (1) above.

So far so good. However, journals are not just places into which papers are submitted. The evaluation process is at the same a renewing process. The acceptance procedure at the same renews the field of science. In this sense, the peer reviewer is not simply a colloquist who looks at the quality of argumentation by using shared standards. He or she is a censor in the sense that he or she will determine which questions are and are not central in the field of science.

Exaggerating somewhat, there are more journals than writers. The journals are therefore in permanent need of acceptable papers. The review process is slow and expensive in such competition. There are several rankings of journals. ${ }^{33}$ The essential thing in scientific reasoning is, as Peirce says, its tendency "to correct itself, and the more so the more wisely its plan is laid". Even if ranking and competition do not contradict the idea of the self-corrective nature of scientific reasoning, one has to plan the ranking system and competition structure in such a way that they support the self-corrective character of science.

The idea of self-correcting implies that there can be mistakes in science. These mistakes can be of any kind, e.g. methodological or factual. Niiniluoto characterizes this aspect as follows:

"The assumption that all so called 'scientific knowledge' is strictly speaking true is an illusion. The growth of science does not simply mean the accumulation of new truths over and above the system of old truths. The development of science includes 'revolutionary' breaks in which the basic concepts and theories have to be re-evaluated." ${ }^{34}$

The possibility of mistakes (fallibilism) and self-correcting in scientific reasoning have to be taken into attention in the methodology of science. In philosophy of science, one central problem is to characterize scientific methods. ${ }^{35}$ For example, objectivity, criticality, autonomy and progress are usually mentioned 
as characteristics of the scientific method or scientific reasoning. We will not discuss these more closely here, but they support in a clear cut sense the selfcorrecting nature of scientific reasoning.

We will not consider more closely how well the characterized practice in journals can correct different kinds of mistakes in science. We will start to consider the problem in which the audience is not colleagues of the same field. This opens new kinds of problems. Sometimes it seems that the problems we discussed above are not recognized at all in the interdisciplinary context.

\section{Popularization}

To get a better grasp of the interdisciplinary problematic, let us briefly consider the popularization of science. In a nutshell, popularization consists of sharing scientific knowledge with a wider public. Such a wider public may include (among others) scientists of other fields of science, other professionals, citizens, students or children of all ages. ${ }^{36}$

The audience of the popularization does not share the same paradigm or have a common understanding of formula (1). This implies that the interesting problems in popularization are not the same as in the case of scientific inquiry: for a scientist, the most interesting problems are problems in the field of science, in popularization the interesting problems are about the field of science. In fact, Enlightenment is a philosophy of popularization: the idea of Enlightenment was to teach humans to use their own reason. This is exactly what the very intention of popularization is.

The topic of a popular text is not the same as that of a scientific text. In scientific inquiry one is solving a problem in a science. The paper will connect the problem to other central problems in the field and eventually solve the problem. In popularization, the writer characterizes some general aspects of the problematic. The characterization is done by using simplifying examples that can be understood without some specific knowledge in the field of science. How can this be possible?

Let us use the interrogative model in characterizing the problem here. In (1), the inquirer knows $\mathrm{M}$ and $\mathrm{T}$; the sentence $\mathrm{C}$ expresses a problem that is shared between colleagues. All the inquirers are working with the same problem, namely C. They have the same background knowledge, namely T. Usually, they also have the same application, namely $\mathrm{M}$. The shared forums of publications and discussions, books, journals, and conferences, allow this to be the actual case. As we recognized, a colleague acts as a peer reviewer in a natural way.

In the case of popularization, the very intention is not to do science, but to tell about science. That is, the whole schema (1) is the object of discussion. The audience does not know much about the theory or about the applications of the theory. So, the theory T and the model M are not known by the audience.

32

Albert Geoffrey Howson \& Jean-Pierre Kahane (eds.), The Popularization of Mathematics, Cambridge University Press, New York 1990.

33

See, e.g.: http://www.journal-ranking.com/ran king/web/index.html.
See, e.g.: I. Niiniluoto, Critical Scientific Realism; and V. F. Hendricks, The Convergence of Scientific Knowledge - A View from the Limit.

36

A. G. Howson \& J.-P. Kahane (eds.), The Popularization of Mathematics.

34

I. Niiniluoto, Is Science Progressive?, p. 6. 
Hence, the audience cannot understand the proper meaning of the problem sentence $\mathrm{C}$ either. This shows why the examples in popularization are simpler than those in scientific research. The simplicity may also be of theoretical character. How can one tell about science in such a situation? What can the audience in principle understand about the topic? How does one apply the information given?

The inquirer has a real problem in formulating a popular characterization of his or her inquiry. In a sense, it is a quite specified problem to formulate a paper for some specified segment of the audience, for example, for laymen who just want to get some information about the research work. However, the problem becomes intensified if the audience is a group of professionals in other fields: they need well formulated, true knowledge that can be used in several different situations. Unfortunately, there is no such context independent knowledge that could be applied in any situation. The knowledge should be localized to the situation. ${ }^{37}$

\section{Multidisciplinary inquiry}

Multidisciplinary inquiry refers to inquiry where at least two different fields of science are used. Let us use the interrogative model in the analysis of the situation here. Let $\mathrm{T}^{\prime}$ and $\mathrm{T}^{*}$ be two theories. They have applications and problems of their own. Let $\mathrm{C}^{\prime}$ and $\mathrm{C}^{*}$ be problems of $\mathrm{T}^{\prime}$ and $\mathrm{T}^{*}$, respectively. To make the situation interesting, $\mathrm{C}^{\prime}$ and $\mathrm{C}^{*}$ need to have some connection. The applications in which the problems are considered are $\mathrm{M}^{\prime}$ and $\mathrm{M}^{*}$, respectively. So, we have the following situation:

(2) $M^{\prime}: T^{\prime} \vdash C^{\prime}$.

$\mathrm{M}^{*}: \mathrm{T}^{*}+\mathrm{C}^{*}$.

In (2), the problem situations are separate. To unify them we have to construct an application $\mathrm{M}$, into which both $\mathrm{M}^{\prime}$ and $\mathrm{M}^{*}$ can be embedded:

(3) $\mathrm{M}^{\prime} \subseteq \mathrm{M}$ and $\mathrm{M}^{*} \subseteq \mathrm{M}$.

Condition (3) is not easy to satisfy. For example, this supposes that there is a language $\mathrm{L}$ which is an extension of the languages of the theories $\mathrm{T}^{\prime}$ and $\mathrm{T}^{*}$. This may allow us to formulate a common problem $\mathrm{C}$ which is an extension of the problems $\mathrm{C}^{\prime}$ and $\mathrm{C}^{*}$. This can be done in the extended language and the interpretation is given in the extended theory $\mathrm{T}$ in the extended application $\mathrm{M}$. In logic, there are several results that show how this can be done. ${ }^{38}$

Multidisciplinarity is a situation where one refers to practical problems in which several different fields of science and vocations are needed. ${ }^{39}$ The notion of a peer is not well defined in this kind of situation. This implies that the choice of referee is not easy: from which field of science should he or she come from? Moreover, it is not clear in which sense this kind of approach generates a new kind of scientific approach.

\section{General situation: new kind of research orientation}

In philosophy, the focus has been on the analysis of existing scientific theories. The idea has been to analyze sciences that explain the world, not sciences that change the world. However, the latter topic has become more central within 
the last few decades. The developments in history of science (e.g. Kuhn) and sociology of science (e.g. Latour) have pointed at this direction. ${ }^{40}$

However, as we saw, the interrogative model gives a formal tool to analyze the situation precisely. Even if the analysis would be precise, there is a need for more general philosophical discussion. Let us consider the following quotation.

"A counterpartal inquiry is one in which the co-inquirers include, for example, both doctors and patients, or health visitors and some members of the families they visit, and the inquiry is about the practitioner-client relationship and what it is seeking to achieve. We have not yet heard of any full counterpartal role inquiries (...) but they are extremely promising and are bound to occur sooner or later in the interests of client empowerment and practitioner deprofessionalization." 41

The idea in the quotation is that there could be a new kind of research, called 'counterpartal inquiry', in which inquirers and practitioners cooperate. However, the quotation does not state very clearly what kind of research will appear here. For sure, doctors and patients have been cooperating all the time, but usually a doctor's healing relationship is not included in medical research. ${ }^{42}$ However, it is worth further study to consider the possible cooperation between professionals and laymen.

Heron and Reason also characterize another kind of multidisciplinary research approach. They call it 'mixed role inquiry':

"A mixed role inquiry is one that includes different kinds of practitioner. If they do not work together, they may explore similarities and difference in their several modalities of practice. If they collaborate, then they may focus on aspects of this, as in inquiry involving general medical practitioners and various complementary therapists exploring issues of power and conflict involved in their collaboration." 43

In this case, a similar general note can be made. Mixed role inquiry is very important. The approach will generate new information. However, what is not so clear is what kind of inquiry Heron and Reason are formulating here. Inquiry is not merely cooperation, not only generating new skills or generating new knowledge. Scientific inquiry is a special case of knowledge acquisition. It is important to uphold the distinction between basic and applied inquiry and de-

37

See: Arto Mutanen, "Methodology of engineering science as a combination of epistemic, ethical, and aesthetic aspects", in: Steen Hyldgaard Christensen, Martin Meganck \& Bernard Delahousse (eds.), Philosophy in Engineering, Academica, Aarhus 2007; and Arto Mutanen, "Deliberation - Action - Responsibility: Philosophical Aspects of Professions and Soldiership", in: Jarmo Toiskallio (ed.), Ethical Education in the Military. What, How and Why in the 21st Century, ACIE Publications, Helsinki 2007.

38

Wilfrid Hodges, Model Theory, Cambridge University Press, Cambridge 1993.

39

See, e.g.: Jack Stilgoe, Citizen Scientist: Reconnecting Science with Civil Society, Demos, London 2009; and P. Reason \& H. Bradbury, Handbook of Action Research.
40

I. Niiniluoto, The Aim and Structure of Applied Research.

41

John Heron \& Peter Reason, "Extending epistemology within a co-operative inquiry", in: P. Reason \& H. Bradbury, Handbook of Action Research, p. 147.

42

See: Ritva Engeström, "Voice as Communicative Action", Mind, Culture and Activity, 2 (3/1995), pp. 192-215.

43

J. Heron \& P. Reason, "Extending epistemology within a co-operative inquiry", p. 147. 
velopment. All the examples given by Heron and Reason refer to something that could be classified as development.

The conceptual distinction between basic and applied science and development is difficult to make out in practice. The reason is that in practical life things do not appear separately. However, this practical difficulty does not imply that the conceptual distinction would be worthless. In a sense, the quotations above show the importance of such conceptual distinctions: it is very important that we carefully separate the search for new knowledge (basic inquiry), the search for applications of knowledge (applied science), and the factual application of knowledge (development). In fact, in philosophy of science the emphasis has been on the first of these. ${ }^{44}$ However, in the quotations above, the separation between basic and applied inquiry and development has not been done. Because of the mix-up, it is very difficult to understand what is going on in such a new kind of inquiry.

The interconnection between practice and theory is of central importance. There are a lot of important questions to be asked. In fact, the problem has been considered in philosophy for hundreds of years; it was considered already in antiquity. The tradition of the maker's knowledge is perhaps the most famous example of such a consideration. In Politics, Aristotle generalized the discussion also to the user's knowledge.

Technology has been a growing area in philosophy of science. "By technology I mean the design and use of material and social artefacts which function as tools in the interaction with and the transformation of reality". ${ }^{45}$ Using the distinction between basic and applied science and development, it is easy to see that technology is not basic science. However, according to the characterization given by Niiniluoto, technology is not included in applied sciences either:

"Engineering science, agricultural and forestry sciences, medical sciences, and practical social sciences are often mentioned as examples of applied sciences. Falling between basic science and technology, they produce new knowledge which is intended to be useful for the specific purpose of increasing the effectiveness of some human activity." 46

The distinction between basic and applied science and development is not an evaluative distinction. We are not saying that one of them would be better than the other. The distinction is conceptual and based on the different kinds of goals of the activities. The non-evaluative character is essential here: the essential thing is clear conceptual analysis of the activity. Technology is as intelligent as it is, independent of whether one locates it in any of the classes: the classification does not change the activity.

\section{Remystification of science}

The non-evaluative character is not, however, as obvious as we mentioned above. One may feel conceptual distinctions to also be evaluative. Let us consider the following quotation from Heron and Reason:

"The Apollonian inquiry takes a more rational, linear, systematic, controlling and explicit approach to the process of cycling between reflection and action. (...) The Dionysian inquiry takes a more imaginal, expressive, spiralling, diffuse, impromptu, and tacit approach to the interplay between making sense and action." ${ }^{47}$

The distinction between Apollonian and Dionysian inquiry is quite difficult to understand. The reason is that the basis of the distinction is not clear enough. First, the basis of the distinction has deep philosophical roots. However, the 
characteristics listed are not as explicit as they should be. For example, rationality, systematicity and explicitness are quite desirable properties - or are they? In fact, rationality is sometimes interpreted as non-creative, something computable. This interpretation is a very problematic one. ${ }^{48}$ However, what about the characters of Dionysian inquiry? Are being impromptu, diffuse etc. really positive properties in an inquiry? What happens to, for example, the open critical argumentation that is supposed in scientific research? In the case of disagreement, an arguer may say that his research is in the Dionysian approach, which trusts intuitive and non-linear argumentation. What can an Apollonian researcher answer?

The distinction between Apollonian and Dionysian inquiry does not start dialogue between the parts. Such an evaluative distinction tends to lock up the parts into their own fields. Such an attitude tends to mystify science.

\section{Science war}

Pegging different kinds of activities against each other is not a fruitful starting point. Evaluation is, of course, part and parcel of science. The evaluation of scientific research is a central task of the scientific community. However, the evaluation should be dialogical: internal, critical and open discussion within the scientific community. This is an extremely difficult task, though: it can hardly be done within mature fields of science. How could it be done in an interdisciplinary manner?

Alan Sokal wrote a paper which was accepted into a journal using peer review evaluation. ${ }^{49}$ The journal was a leading one in its field of inquiry. After publication, Sokal revealed that the paper was just a parody. Sokal was trying to show the anti-intellectual aspects of postmodernism. The episode started a so-called science war between two cultures. The war is still going on.

The science war is not just a conflict within the scientific community. In fact, in the scientific community several conflicts are taking place all the time: conflicts are a part of scientific discussion. But in this specific conflict, there seem to be deeper reasons. The problem arises if the deeper reasons will not become the topic of discussion. The discussion seems to be not a dialogue, but a war:

"Over the last three years we have participated in numerous debates with sociologists, anthropologists, psychologists, psychoanalysts, and philosophers. Although the reactions were extremely diverse, we have repeatedly met people who think that assertions of fact about the natural world

44

I. Niiniluoto, Critical Scientific Realism.

45

I. Niiniluoto, The Aim and Structure of Applied Research, p. 4.

46

Ibid., p. 5 .

47

J. Heron \& P. Reason, "Extending epistemology within a co-operative inquiry", p. 148.

48

See: Arto Mutanen, From Computation to Truth via Learning, University of Helsinki, Helsinki 2004.
See: Alan Sokal, "Transgressing the Boundaries: Toward a Transformative Hermeneutics of Quantum Gravity", Social Text 46/47 (1996), pp. 217-252.

50

Jean Bricmont \& Alan Sokal, "Science and Sociology of Science: Beyond War and Peace", in: Jay Labinger \& Harry Collins (eds.), The One Culture? A Conversation about Science, University of Chicago Press, Chicago 2001, pp. $27-47$. 
can be true 'in our culture' and yet be false in some other culture. We have met people who systematically confuse facts and values, truths and beliefs, the world and our knowledge of it. Moreover, when challenged, they will consistently deny that such distinctions make sense." 50

Bricmont and Sokal refer to relativism. However, the problem is not relativism as such. Relativism is not a single doctrine, but a family of different approaches. Some of them are more justified than others. ${ }^{51}$ The problem in the present discussion is that relativism seems to be a kind of tool: one party in the war just hits with the tool, and the other party in the war just hides the problems behind the tool. There is no open discussion about the real topic.

\section{Search for a proper dialogue}

Proper discussion is difficult to build. One reason is the journal system. Each field of science has journals of its own. How does one then generate interdisciplinary discussion? As we noticed, interdisciplinarity is a conceptually difficult topic. In fact, the logic of scientific discussion is against interdisciplinarity: an interdisciplinary approach, in order to be scientific, has to generate "field" of its own - its own journals, research groups, etc. ${ }^{52}$

In science, specialization is necessary: inquirers are specialists, journals are specialized, research organizations are specialized etc. In fact, the peer review system does not help the scientific community to have interdisciplinary discussion: inquirers write to peer reviewers - censors; in mature fields of science, the system cuts off opinions that seem to be too radical or too critical to be accepted into the discussion, and in interdisciplinary fields, the system guarantees that the own paradigm will have the last word.

(Un)fortunately, the internet makes the situation much more complex. There are several different kinds of journals, different kinds of expert pages and different kinds of expert discussion groups that generate "knowledge of their own". It is not an easy task to orient oneself in this situation: there are no peers and no referees. It seems that we have stabilized the war in such a way that each party in the war has the place they have.

In science, open critical discussion is not merely a desired situation. Open, critical discussion is a methodological constraint: without it there is no scientific research. The discussion should be about the topic, not about the science war. Let us generate proper discussion, proper dialogue. The intended dialogue is interdisciplinary dialogue in which the participants have different backgrounds but a common interest, a common topic. The forums of dialogue can be both scientific conferences and scientific journals. However, the topic should be the last referee in the discussion. In this task, philosophy has a constructive role: let philosophy build a bridge into interdisciplinary dialogue. 


\section{Arto Mutanen}

\section{Znanost i komunikacija}

\section{Sažetak}

Komunikacija u znanosti je u osnovi uspostavljena kao komunikacija između razgovora unutar nekog znanstvenog područja. Znanstveni časopisi, konferencije itd. su temeljene na ovom principu. Naprimjer, pojam peer reviewa pretpostavlja takav kolegijalan, monodisciplinaran okvir. Međutim, multidisciplinarna istraživanja i angažman oko praktičnih problema primoravaju nas da situaciju sagledamo na novi način. Što bi mogla značiti multidisciplinarna rasprava? Kako izgraditi takvu raspravu? Je li takva rasprava samo sukob između nepomirljivih mišljenja - rat znanosti? U ispravnom dijalogu konačni sudac bi trebala biti praksa, a ne znanstvena teorija.

\section{Ključne riječi}

filozofija znanosti, ispitivački model, monodisciplinarna istraživanja, multidisciplinarna istraživanja, rat znanosti, dijalog

\section{Arto Mutanen}

\section{Wissenschaft und Kommunikation}

\section{Zusammenfassung}

Die Kommunikation in der Wissenschaft wird grundsätzlich als Kommunikation unter den Kolloquien eines bestimmten Wissenschaftsbereichs hergestellt. Wissenschaftliche Zeitschriften, Konferenzen usw. fußen auf diesem Prinzip. Beispielsweise setzt die Vorstellung vom Peer-Reviewer einen solchen kollegialen, monodisziplinären Rahmen voraus. Jedoch nötigen uns multidisziplinäre Forschungen und Engagement um praktische Angelegenheiten, die Situation in neuem Licht zu besehen. Was für eine Bedeutung kann multidisziplinäre Diskussion haben? Wie lässt sich eine solche multidisziplinäre Diskussion aufbauen? Ist eine solche Diskussion bloß ein Tauziehen zwischen den unverträglichen Ansichten - ein Krieg der Wissenschaften? In einem ordentlichen Dialog sollte die Praxis der endgültige Arbiter sein, nicht die wissenschaftliche Theorie.

\section{Schlüsselwörter}

Philosophie der Wissenschaft, interrogatives Modell, monodisziplinäre Forschung, multidisziplinäre Forschung, Krieg der Wissenschaften, Dialog

\section{Arto Mutanen}

\section{Science et communication}

\section{Résumé}

La communication en science repose essentiellement sur la communication entre colloques dans un domaine scientifique donné. Les journaux scientifiques, les conférences etc. sont basés sur ce principe-là. Par exemple, le concept de peer review suppose un tel cadre collégial, monodisciplinaire. Cependant, la recherche multidisciplinaire et l'engagement sur les problèmes concrets nous poussent à nous pencher sur la situation d'une manière nouvelle. Que pourrait bien vouloir signifier un débat multidisciplinaire? Comment construire un tel débat? Un tel débat n'est-il que conflit entre positions inconciliables, une guerre des sciences? Dans un dialogue correct, c'est la pratique, pas la théorie, qui devrait être juge.

\section{Mots-clés}

philosophie de la science, modèle interrogatif, recherche monodisciplinaire, recherche multidiscipliniaire, guerre des sciences, dialogue

51

See I. Niiniluoto, Critical Scientific Realism.
52

I. Niiniluoto, Critical Scientific Realism; and I. Niiniluoto, Is Science Progressive? 